\title{
JULIUSZA SŁOWACKIEGO KONCEPCJA POEZJI. O TWÓRCZOŚCI KORESPONDUJĄCEJ Z MUZYKĄ I MALARSTWEM
}

\author{
Juliusz Stowacki's Concept of Poetry. \\ On Works Corresponding to Music and Painting
}

Keywords: arts correspondence, poetry, painting, music

Contact: Uniwersytet Humanistyczno-Przyrodniczy im Jana Dlugosza w Częstochowie; klaudia.pompa@gmail.com

Chodzi mi o to, aby język giętki Powiedział wszystko, co pomyśli głowa:

A czasem był jak piorun jasny, prędki,

A czasem smutny jako pieśn stepowa,

A czasem jako skarga nimfy miętki,

A czasem piękny jak aniołów mowa ... Aby przeleciał wszystka ducha skrzydłem.

Strofa być winna taktem, nie wędzidłem.

(J. Słowacki Beniowski)

Wykreowany przez Słowackiego świat to przede wszystkim apoteoza słowa, w którym w niebagatelny sposób odbija się malarski pędzel i fala dźwięków. Wydawać by się mogło, że romantyczny poeta jest prestidigitatorem, zręcznie stosującym ideę corespondance des arts, co pozwala mu uzyskać poetycką magię, w której rozbrzmiewa wewnętrzna muzyka pisana obrazami. Nie bez powodu J. Tenner mówi o nim, że jest „nieporównanym i niedoścignionym twórcą muzyki języka” (Tenner 1910: 509). Wyobraźnia i przedstawienie u Słowackiego wpisują się w powszechnie znaną pisarzom XIX wieku romantyczną syntezę sztuk, która z kolei, w myśl za Heglem związana jest z poetyckim natchnieniem: „Jakże często się słyszy twierdzenie, że artysta powinien 
treść swoją czerpać tylko z samego siebie. Rzecz jasna, że może zajść taki wypadek, np. kiedy poeta «śpiewa jak ptaszek wśród gałęzi drzew». Bodźcem jest tu jego własna pogoda ducha, która jako przeżycie wewnętrzne może sama stać się tematem i treścią, skłaniając do artystycznego wykorzystania swego radosnego nastroju. Wtedy też «pieśń, która się z piersi wydobywa, stanowi sowitą nagrodę»» (Hegel 1964: 459).

Czy Słowacki posiadał ową ,pogodę ducha” mogącą tworzyć pieśni? Niewątpliwie jego zmysłowa osobowość pozwalała mu na czerpanie z natury jak z wielkiego słownika znaków, obrazów i dźwięków, a czucie „duszy świata” i bezpośrednia więź z wszechświatem i Bogiem była przejawem natchnionej wyobraźni poetyckiej.

Biografia Juliusza Słowackiego pokazuje, że jest to osoba, która już od najmłodszych lat miała kontakt ze sztuką, a muzyka i malarstwo były stałym elementem budującym wczesną wyobraźnię poety. „Imaginacja moja młoda jak motyl, wabiona była połyskiem, słońcem, kształtami” (Słowacki 1949, t. 10: 131) pisał Słowacki, wspominając swoje pierwsze utwory. To właśnie zdobyte w młodzieńczym wieku doświadczenie estetyczne, wzorkowe pochłanianie dzieł sztuki, obcowanie z późnobarokową przestrzenią Wilna, sprawiły, że w pamięci na stałe zakorzeniło myślenie obrazami. Warto przywołać tutaj badania Andrzeja Nowaka, które dowodzą, że znaczna część naszej wyobraźni jest związana z osobistym zakorzenieniem w pamięci „fotografii” rzeczy przyswojonych, poznanych przed 18. rokiem życia. Te przyzwyczajenia estetyczne kształtują nasze późniejsze myślenie i zainteresowania, gusta. Powiązane jest to z kategorią „myślenia wyobrażeniowego”, które u niektórych ludzi przoduje, bywa pierwotne od „myślenia słowami”. Taki właśnie aparat poznawczy, wielobarwne klisze przepełnione malarstwem włoskim, sakralną, uduchowioną atmosferą kościołów wileńskich są dla poety niezwykle ważne w kontekście jego pracy nad słowem poetyckim. W starannie odebranym wychowaniu nie zabrakło także lekcji gry na fortepianie, pobieranych u Wilhelma Focka ${ }^{2}$. Z listów pisanych do matki dowiadujemy się, że poeta miał żal do nauczyciela o techniczne braki: „Co się tyczy fortepianu, przez tę zimę znacznie poczyniłem postępy w czytaniu nut, ale Foka przeklinam, że mnie gamy, prostej gamy nie nauczył. Biegłości mi płynnej braknie i dlatego ludzie, którzy się na czuciu nie znają, a tylko sypanie grochu w grze wielbią, nic nie uwielbią w moim melodyjnym talencie" (Słowacki 1949, t. 6: 292).

\footnotetext{
1 Zob. Nowak, A. Wyobrażeniowe mechanizmy przetwarzania informacji: myślenie przestrzenne. WocławWarszawa-Kraków, 1991.

${ }^{2}$ Zob. Hertz, P. Portret Stowackiego. Warszawa, 1976, s. 16.
} 
Pomimo różnych przeszkód, nie zniechęcał się. Grał często, głównie fragmenty znanych operetek, oper oraz popularnych melodii tanecznych ${ }^{3}$. Jasno dawał do zrozumienia że jego muzyka pochodzi z wnętrza duszy. By ją zrozumieć potrzeba „czuć” dźwięki, a niekoniecznie grać poprawnie „sypiąc groch”. Wg Słowackiego najpiękniejsza muzyka to ta, która kojarzy się ze wspomnieniem, dlatego uwielbiał i cenił twórczość Johna Fielda. Próbował także swoich zdolności grając Chopina, o Ronda à la Krakowiak F-dur, op. 14 pisał, że jest ,prześliczny, ale trudny jak diabeł”. Zaskakujące a jednocześnie bardzo piękne jest to, że wielu badaczy upatruje domniemanego powinowactwa biograficznego Słowackiego z Fryderykiem Chopinem. Nie chodzi tylko o sam fakt, że obaj artyści umarli na tę samą chorobę i w podobnym wieku. Norwid w „Czarnych kwiatach” przywołuje pewien zbieg okoliczności, w którym Słowacki nazywa Chopina „morybundem”, a pod koniec rozmowy mówi: „Piersi, piersi nadwerężone mam, każą mi już tylko cukierki jeść, co chwilowo łagodzi kaszel, żołądkowi za to o tyleż szkodząc. Przyjdź jeszcze w przyszłym, w zaprzyszłym tygodniu, potem... czuję, że niezadługo i odejść z tego świata przyjdzie mi” (Norwid 1968: 39-40). Ironiczne określenie kompozytora jest jak gdyby siłą jednoczącą, utożsamiającą dwie wybitne jednostki, co po latach zauważy Stanisław Tarnowski pytając: „Nie jest to zbliżone szczególnie, że z tą poezją równocześnie ustaje i muzyka Chopina? Czy to nie jest jak gdyby stwierdzeniem, że one do siebie należały, że miały jedno życie i jedną duszę?” (Tarnowski 1892: 44). Dziesięć lat później na to pytanie odpowie niejako F. Hoesick, który w artykule dotyczącym paraleli Słowackiego z Chopinem napisze: „Zaprzeczyć się bowiem nie da, że pomiędzy poezją Słowackiego a muzyką Chopina istnieje jakaś goethowska Wahlverwandschaft, że łączy je mnóstwo cech pokrewnych, że przy czytaniu W Szwajcarii lub Beniowskiego duszę ogarnia rozmarzenie, jak przy melancholijnych dźwiękach nokturnów lub niektórych preludiach Chopina, i że nie wyda się paradoksalnym stwierdzeniem, jako muzyka Chopina to poezja Słowackiego przetłumaczona na język tonów i odwrotnie" (Hoesick 1902: 2).

Pomimo, że obaj romantycy nie darzyli się sympatią, to jednak sztuka odzwierciedlająca polską XIX wieczną kulturę była zespolona „duchem

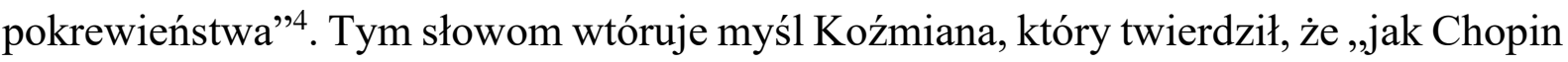
był najwznioślejszym poetą w muzyce, tak Słowacki najsubtelniejszym muzykiem w poezji”. I właśnie o ową „muzyczność” poezji chodziło przede wszystkim

\footnotetext{
${ }^{3} \mathrm{~W}$ jednym z listów do matki pisał: „,(..) otóż donoszę Ci, że gram bardzo często, ale tylko fantazje i słyszane aryjki z oper. Największą mi przyjemność robi jeden polonez Sokołowskiego, którego sobie przypomniałem" (Słowacki 1949, t. 6: 117).

${ }^{4}$ Mario Praz pisał, że: „Istnieje duch pokrewieństwa między wszystkimi dziełami sztuki powstałymi w tej samej epoce". Mnemosyne. Rzecz o powinowactwie literatury i sztuk pięknych. Tłum. Jekiel, W. Warszawa, 1981, s. 61. ${ }^{5}$ Anonimowy nekrolog pióra Jana Koźmiana zamieszczony w „Przeglądzie Poznańskim” (Poznań 1848, t. 9, s. 688). Autorstwo stwierdzono na podstawie Pism Koźmiana (Poznań 1881, t. 3, s. 217-218). Cyt. za: Sądy
} 
Krasińskiemu, gdy mówił, że Słowacki „nie rzeźbiarzem, ale muzykiem się urodził; a w tej jego muzyce niesionej nutami Betowena, płyną farby Correggia, farby Rafaela" (Krasiński 1841: 192). „Muzyczność”, która znaczy tyle co ruch, pęd, siła ośrodkowa, starająca się „,ciągłym drganiem cząsteczek i roztapianiem kształtów wyrazić westchnienia wszystkich ciał natury i rwania się wszystkich myśli ducha ku niewidzialnemu światu nieskończoności” (Krasiński 1841: 180). Dźwięki tworzące imaginację Słowackiego, towarzyszyły mu w odczuwaniu świata, dlatego możliwe jest usłyszenie ich $\mathrm{w}$ jego twórczości. Ta muzyka powstaje nie tylko w warstwie organizacyjnej wiersza, lecz także, a może i przede wszystkim w warstwie tematycznej utworów. W dziełach poety pełno jest instrumentów, muzyki, śpiewów. Zdawać się może, że świat odgrywa swój wielki koncert, w którym Słowacki jako dyrygent wyłapuje czułe drgania. Utwory często określane są jako pieśni, hymny, dumy, których różnorodność dźwiękowa i bogactwo przywoływanych instrumentów tworzą symfonię dźwięków ${ }^{6}$, brzmiącą w uszach czytelnika. Są to - jak określił je Krasinski - ,arcydzieła wnętrznej melodii ducha". Muzyczność Słowackiego jest zmienna w zależności od okresu pisarskiego. Jego młodzieńcze utwory są przejawem osłuchania się z ludowymi dumkami. Są śpiewne i rytmiczne, bowiem „Słowacki, tak jak nikt inny w Polsce, odczuwał odrębną muzykalność słowa, wiedział, że elementy muzyki - rytm i śpiewność - mogą być tylko podkładem dla tonu słowa, że słowo ma swoją własną całkiem odrębną muzyczność" (Kleiner 1923: 196). Spróbujmy spojrzeć na początkowe fragment „Żmii. Romansu poetycznego z podań ukraińskich w sześciu pieśniach”:

Piękny to widok Czertomeliku, Sto wysp przerżnęly Dniepru strumienie, Brzoza się kąpie w każdym strumyku, Słychać szum trzciny, słowika pienie.

A kiedy wiosną wezbrane wody Zaleją wszystkie wyspy dokoła; Jeszcze nad wodą widać drzew czoła, Jakby rusałek cudne ogrody. Gałązką mącą wodne błękity, I jeszcze słowik w gałązkach śpiewa, I szumią brzozy, lecz nad ich szczyty Wznosi się fala i nikną drzewa.

Dziko Dniepr szumi, gdy w jego łonie,

$$
\begin{aligned}
& \text { - }-\ldots \text { - } \| \text { _ } \ldots \text { - } 10 \\
& \text { - }-\ldots \text { - } \| \text { _ }-\ldots 10 \\
& \text { - }- \text { - } \| \text { - }-{ }_{-}-10 \\
& \text { - }- \text { - }-\| \ldots+\ldots \\
& \text { - }-\ldots \| \text { - } \ldots+\ldots 10
\end{aligned}
$$

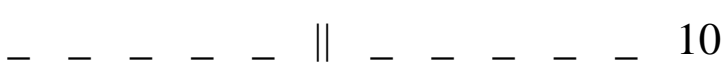

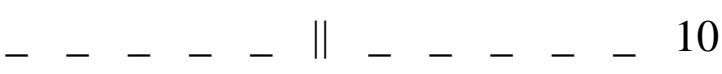

$$
\begin{aligned}
& \text { - }-\ldots\|\| \ldots \\
& \text { - }-\ldots \text { - } \| \text { - } \ldots \text { - } 10
\end{aligned}
$$

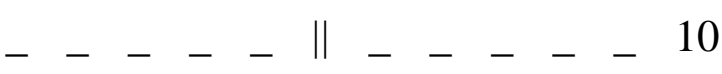

$$
\begin{aligned}
& \text { - }- \text { - } \| \text { - }-\ldots \\
& \text { - }- \text { - }-\| \ldots+\ldots
\end{aligned}
$$

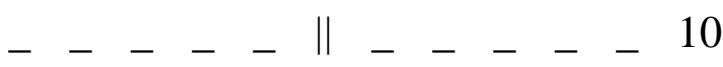

wspótczesnych o twórczości Stowackiego (1826-1862), zebrali i opatrzyli B. Zakrzewski, K. Pecold, A. Ciemnoczołowski, Wrocław, 1963, s. 299.

${ }^{6}$ Symfonię w znaczeniu leksykalizacji pojęcia muzykologicznego. 
Sto wysp zielonych wiosną zatonie.

$-{ }_{-}-\|_{-}-{ }_{-}-{ }_{1} 10$

Dziesięciozgłoskowy wers ze średniówką po 5 sylabie i rymy dokładne niepodważalnie tworzą rytmiczność utworu. Oprócz warstwy organizacyjnej ważną rolę odgrywają także słowa, które grają w uszach. Czytelnik zagłębiony w tekst może usłyszeć szelest traw, szum strumienia, śpiew ptaków etc. Całość jest niczym muzyka, którą słychać podczas czytania. Jej dźwięki pochodzą zarówno od poety, jak i z natury, ponieważ wg poety brzmiał także świat empiryczny: „Czasem go słychać w letniej błyskawicy, / Czasem w błękitach gra - a czasem we mnie".

Dodatkową śpiewność utworu poeta uzyskał przeplatając fragmenty 10zgłoskowe 5-zgłoskowymi. Czytany tekst sprawia wrażenie słów grających swoje crescendo i diminuendo, dłuższe i krótsze frazy. To uczucie dodatkowo potęguje zapis tekstu: wyposażenie w wykrzykniki dłuższych i mocniejszych tonów oraz nagromadzenie czasowników, które wzmacniają tempo i podkreślają dynamikę. To, co mogło by kojarzyć się z wyciszeniem, zmniejszeniem napięcia, jest usytuowane na środku, jak gdyby otoczone pauzami, ciszą po jednej i po drugiej stronie swojej melodii.

Ty spisz, sumaku! ty spisz, sumaku!

Między błyszczące rosą czahary;

$$
\begin{aligned}
& --------10 \\
& \text { - } \quad \text { - }- \text { - } \quad \text { - }-10 \\
& \text { - }-\ldots \text { - }-\ldots-10 \\
& -{ }_{-}-{ }_{-}-\ldots-10 \\
& \text { - }- \text { - }-\ldots-\text { - } 10
\end{aligned}
$$

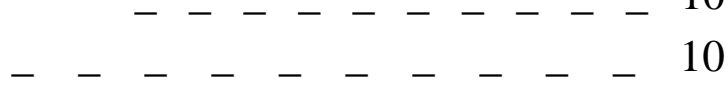

$$
\begin{aligned}
& \begin{array}{r}
-----5 \\
-\quad-\quad-\quad 5
\end{array} \\
& -----5 \\
& ----\quad 5 \\
& -\quad-\quad-5 \\
& ----\quad 5 \\
& -------8
\end{aligned}
$$

A tutaj strzelce w stepach Budziaku,

Otoczą wkrótce knieje i jary.

Sumak nie słyszy! sumak nie słyszy!

Bo milcząc strzelce idą na łowy,

I coraz ciszej,

Między parowy,

Pomiędzy trawy,

Toną i toną;

A zorza płoną,

I świt jaskrawy

Pozłaca niebo na wschodzie.

Rytm i śpiewność to główne elementy wczesnych utworów Słowackiego. „Żmija jest głównie popisem rytmicznym. (...) Silnie podkreślony takt muzyczny, frazowanie, dzielone przez wybijanie rytmu, pojęte w duchu ludowego zamiłowania do silnej rytmiczności. (...) Równość taktowa kształtuje wiersze. (...) To poemat ruchu, przejmujący całkowicie ruchowe piętno kozackiej poezji Zaleskiego i metodę malowania ruchu przez rytm" (Kleiner 1923: 141-142). 
Z kolei w „Lambrze” - powieści poetyckiej w dwóch pieśniach na plan pierwszy wyłaniają się Hymny aniołów, które rozbrzmiewają wokalnie:

Skonały dzikie dwóch aniołów pienia.

Lambro je we snach gorączkowych składał.

Hymn ostatniego tak rymami spadał,

Jak gdyby w piersi marzeń brakło tchnienia.

Przywołując w tym krótkim zarysie utwory określane przez Słowackiego jako pieśni, nie może zabraknąć „Beniowskiego”, w którym świat przepełniony jest muzyką: młodość określona zostaje jako „harfa strojna”, bohater, który tęskni ,jęczy harfy tonem”, Beniowski „na gitarze grał i rym śpiewał włoski”, a z ukochaną Anielą spotykał się „kiedy słowiki wywołują śpiewem”. Autor zdawał sobie sprawę z muzyczności utworu:

Ja się zdolnością natchnień bardzo szczycę,

I tu pokażę, że nie jest zmyśloną,

Lecz z moich rymów czyni błyskawicę;

A mym przekleństwom daje siłę grotów.

Czekajcie! - już pieśń zacznę - jużem gotów.

Co więcej, oprócz doskonałej budowy wersyfikacyjnej, utwór przepełniony jest powtórzeniami. Owe powtórzenia motywów, poszczególnych słów są jak repetycje wmuzyce. Powtarzalność „nie-muzycznych” na pozór sekwencji interpretujemy jako muzykę, bowiem ma to związek z „efektem czystej ekspozycji”, a także $\mathrm{z}$,semantycznym nasyceniem”?

Zamek jego stał nad rzeczką Ladawą

Na skale - a pod skałą staw był wielki.

W tym stawie widać było twarz jaskrawą

Słońca i białe łabędzie Anielki;

lub:

Mimo to jednak Aniela, jak róże,

Co nad wysoki mur liściem wybiegną

\footnotetext{
${ }^{7}$ Powtarzanie to muzyczny fundament, który łączy ludzi na całej Ziemi. Powtarzanie bowiem nie osłabia naszej przyjemności, lecz zwiększa nasze zaangażowanie w muzyczne doświadczenia. Elizabeth Hellmuth Margulis w książce „On Repeat: How Music Plays the Mind” pokazała, co dzieje się ze zbiorami słów, które powtarzane w kółko przestają być znaczeniem czegokolwiek, a stają się jedynie zbiorem dźwięków. ,,Gertrude Stein i inni pisarze awangardowi stworzyli nowy rodzaj literatury z tego żyznego pogranicza, gdzie słowa są nosicielami dźwięku zamiast znaczenia.) Nazywa się to „semantycznym nasyceniem” - momentem, w którym fraza jest przeciążona przez tyle powtórzeń, że wymyka się z przetwarzającej znaczenie części naszego mózgu". Zob. https://www.theguardian.com/music/2016/apr/29/why-we-love-repetition-in-music-tom-service (dostęp z: 202003-30, thum. K. J.).
} 
Patrzeć na słońce - oczy miała duże,

Czarne. - Jak róże, co się nad mur przegną.

W muzycznej twórczości Słowackiego na uwagę zasługują także hymny, zwłaszcza Hymn do Bogarodzicy będący religijno-patriotyczną modlitwą o wolność ojczyzny, do którego muzykę na 4 głosy z fortepianem napisała Amelia Fritsch ${ }^{8}$ wydany w $1831 \mathrm{r}$. w litografii Wyszkowskiego, funkcjonował w obiegu w czasie wojny polsko-rosyjskiej. Utwór utrzymany jest w podniosłym tonie, a jego żołnierski rytm uwydatnia dynamikę i surowość nastroju. Irena Chyła-Szypułowa pisała, że ,śpiewność poezji polega głównie na regularnej pulsacji schematu rytmicznego, powtarzających się układach wierszowych, najczęściej sylabotonicznych oraz rymach" (Chyła-Szypułowa 2000: 120) i owa „pulsacja” hymnu sprawia, że wiersz ma swoją własną melodię, przypominającą odgłosy maszerującego wojska, rytmiczną i donośną.

Jednym z najpopularniejszych hymnów, jest Hymn (Smutno mi, Boże!), zawierający osobistą refleksję nad własnym życiem. Pomimo, że utwór nie realizuje założeń gatunkowych, a swoją budową odbiega od konwencji literackich, to jednak pokazuje jak ważną rolę odgrywał ten gatunek w myśleniu poety. Hymn jest czymś więcej niż zwykłą pieśnią, jest formą szlachetną, bardziej uroczystą, co potwierdza autor w Odpowiedzi na „Psalmy przyszłości”:

W takim hymnie, wieszczu, stój:

Bo pieśn taka pójdzie górą,

Nad podlejszych dusz naturą

Panująca (...)

Muzyka jako „siostrzana sztuka” poezji była dla Słowackiego niezmiernie ważna. W wierszu (Przez furie jestem targan ja Orfeusz) poeta utożsamia się z trackim lirnikiem - mówi o sobie ,ja Orfeusz” co znaczy także ,ja poeta” i ,ja pieśniarz” dowodzi, że te dwa dyskursy mogą mówić wspólnym językiem. Istnieje klamra spajająca słowo z dźwiękiem - tą klamrą jest język poetycki. Potwierdzeniem ten jedności mogą być tworzone przez poetę parafrazy Psałterza Dawidowego. O poezji, która zespolona jest niejako $\mathrm{z}$ muzyką jak dusza $\mathrm{z}$ ciałem, mówił Mickiewicz w wykładach o literaturze słowiańskiej: „Cóż to jest (...) poezja bez liry? Kim są poeci, którzy niby śpiewają, nie tylko nie układając muzyki do swych pieśni, ale zgoła nie słysząc jej w sobie? Muzyka nie jest wtórem towarzyszącym poezji lirycznej, lecz

\footnotetext{
${ }^{8}$ Cyfrowa Biblioteka Piosenki Polskiej, sygnatura: Biblioteka Jagiellońska 362 III musicalia.
} 
stanowi jej istotną część; to jej dusza, życie i światło. Bez muzyki (...) nie masz poezji lirycznej" (Mickiewicz 1955: 168).

Miejscem, które niewątpliwie łączy kompozycje muzyczno-słowne, jest opera. To ona szczególnie ujęła muzykalnego poetę. Widowiskowość, liryzm i towarzyszący temu nastrój, emocje, sprawiły, że poeta przenosił na karty swoich dzieł konstrukcje libretta i efekty operowe. „Na wzór opery dążył do skrótowości akcji, kondensacji wrażeń, spiętrzenia namiętności” (Chyła-Szypułowa 2000: 121). Przykładem dramatów o charakterze librett są: Sen srebrny Salomei, Zawisza Czarny, Ksiądz Marek ${ }^{9}$, a na wzór opery z pewnością została napisana Balladyna. To o niej Aleksander Jabłonowski napisał, że „może być z łatwością przeobrażona w operę"10. W dramacie Słowackiego możemy znaleźć doskonałe arie Chochlika, Skierki, Goplany i Grabca. Fragmenty te przepełnione są muzyką w warstwie strukturalnej i słownej, w której „Muzyka echowa/ Zacznie hymnami powietrznymi dzwonić”, a przed chatką Wdowy słychać „dźwięki luteń". Ciekawym elementem operowym jest duet Goplany i Grabca, a także fragment kończący akt drugi - poprzez śpiew „swatów i drużek” przypomina śpiewany przez chór klasyczny finał operowy. Kleiner zwrócił uwagę także na widowiskowość Balladyny: „nie pogardził w scenie III aktu I i w scenie uczty efektem burzy i nagłych zmian świetlnych (w scenie czarów Goplany) i w scenie końcowej operowo-baśniowy piorun finałem uczynił" (Kleiner 1923: 196).

A. Boleski uznał Słowackiego za „prekursora w zakresie muzyczności liryki” (Boleski 1949: 111), nie ulega wątpliwości fakt, że wszystkie dzieła poety odbijają się muzyką. Słowa jak dźwięki, pozwalają płynąć w duszy nie tylko pisarza, lecz także i czytelnika. Dla każdego będzie to inna muzyka. Jak powiedział Łoś: „Muzykalność wiersza Słowackiego odczuwają wszyscy, choć może nie zawsze i nie w jednakowym stopniu. Na czym ona polega, to dotychczas nie zostało wyjaśnione" (Łoś 1920: 238). Może właśnie ze względu na ową niewyjaśnioną dotąd „muzykalność”, muzyczną recepcją twórczości dość późno zainteresowali się kompozytorzy. W sumie zaopatrzonych w muzykę zostało siedemdziesiąt osiem dzieł Słowackiego, w tym największym zainteresowaniem cieszyły się utwory dramatyczne, a „do osiemnastu dramatów i fragmentów dramatycznych napisano 320 kompozycji" (Seweryn 2008: $48)^{11}$.

\footnotetext{
${ }^{9}$ Zob. Okońska, A. Wpływ opery na dramaty Słowackiego. Muzyka. 1961 (2-3), s. 115-116.

${ }^{10}$ Jabłonowski, A. Pisma. Tom 7. Warszawa, 1913. Cyt. za: I. Chyła-Szypułowa, op. cit., s. 122.

${ }^{11}$ Ze względu na formalne ograniczenia, temat został jedynie przybliżony $i$ wymaga dalszego rozbudowania. 


\section{Summary}

The article outlines issues related to the correspondence of pieces. The introduction outlines research issues, then briefly discusses the issues of "musicality" in Słowacki's works. The quoted fragments show the colorful imagination of the poet.

\section{Literatura}

Boleski, A. Juliusza Stowackiego liryka lat ostatnich (1842-1848). Łódź: Łódzkie Towarzystwo Naukowe, 1949.

Chyła-Szypułowa, I. Muzyka w poezji wieszczów. Kielce: Akademia Świętokrzyska im. Jana Kochanowskiego, 2000.

Hegel, G. W. F. Wyktady o estetyce. Tom 3. Thum. Grabowski, J., Landman, A. Warszawa: PWN, Biblioteka Klasyków Filozofii, 1964.

Hertz, P. Portret Stowackiego. Warszawa: Państwowy Instytut Wydawniczy, 1976.

Hoesick, F. Stowacki i Chopin. Paralela literacka. Kurier Warszawski. 1902 (339).

Kleiner, J. Juliusz Słowacki - dzieje twórczości. Tom 1. Lwów-Warszawa-Kraków: Zakład narodowy im. Ossolińskich, 1923.

Krasiński, Z. Kilka słów o Juliuszu Słowackim. Tygodnik literacki. 1841, s. 21-23.

Łoś, J. Wiersze polskie w ich dziejowym rozwoju. Warszawa: GiW, 1920.

Mickiewicz, A. Literatura słowiańska. Kurs drugi. In: tegoż, Dzieła. Tom 10. Tłum. Płoszewski, L., oprac. Maślanka, J. Warszawa, 1955.

Norwid, C. K. Czarne kwiaty. In: tegoż, Pisma wybrane. Tom 4. Wybrał i objaśnił Gomulicki, J. W. Warszawa: Państwowy Instytut Wydawniczy, 1968.

Nowak, A. Wyobrażeniowe mechanizmy przetwarzania informacji: myślenie przestrzenne. Wrocław-Warszawa-Kraków: Zakład Narodowy im. Ossolińskich, 1991.

Okońska, A. Wpływ opery na dramaty Słowackiego. Muzyka. 1961 (2-3).

Praz, M. Mnemosyne. Rzecz o powinowactwie literatury i sztuk pięknych. Tłum. Jekiel, W. Warszawa: Państwowy Instytut Wydawniczy, 1981.

Sąy wspótczesnych o twórczości Stowackiego (1826-1862). Zebrali i opatrzyli Zakrzewski, B., Pecold, K., Ciemnoczołowski, A. Wrocław: Zakład Narodowy im. Ossolińskich, 1963. 
Seweryn, A. Poezja „,nutami niesiona”. O muzycznej recepcji twórczości Juliusza Stowackiego. Warszawa: Instytut Badań Literackich PAN, 2008.

Słowacki, J. Dzieła. Tom 6. Tom 10. Krzyżanowski, J. (ed.). Wrocław: Wydawnictwo Ossolineum, 1949.

Tarnowski, S. Fryderyk Chopin. In: Tarnowski, S. Chopin i Grottger. Kraków: Księgarnia Spółki Wydawniczej Polskiej, 1892.

Tenner, J. O pierwiastkach muzycznych w poezji Stowackiego. Tom 1. „Biblioteka Warszawska”, 1910. 